\title{
Re/Presenting Artful Pedagogy: Relational Aesthetics in Early Childhood Contemporary Art Experiences
}

\author{
Maria Iafelice
}

Maria E. Iafelice, a program manager at the Toledo Museum of Art, earned a master's in art education in 2013 and a BA in art education in 2009 from Kent State University. Maria's positions in museums and nonprofit organizations have provided her the opportunity to work with young learners and teens, and she currently leads a volunteer workforce and manages projects focused on informal learning. She is particularly interested in the radical changes and pedagogical shifts in contemporary art and their implications for art education. Email: iafelice.maria.e@gmail.com

Young children are experts in creating unpredictable projects akin to the work of contemporary artists and within contemporary art practices. The author utilized a hybrid method of a/r/tography and action research to reveal the relational moments, specifically conversations, collaborative art making, and interactions of early learners. Contemporary art, specifically as it relates to relational aesthetics, has the potential to blend with pedagogy and point to new directions for art education of young children: an artful pedagogy. Art created with a relational aesthetic emphasizes and only exists from participation and interactivity. Within the context of classroom experiences, compelling findings surrounding unpredictable projects and young learners as experts are deeply explored. In particular, implications are brought into focus for visualizing conversations with young learners through art. The connections of relational aesthetics in art education to artful pedagogy are revealed through images of conceptual work by young learners and blurry photographs. Interpreting relational aesthetics with a pedagogical lens led to conclusions that point to an elevated view of the art of young children, a view that reveals the possibilities and further questions for art education that is informed by contemporary art. An artful pedagogy suggests that art education catch up with contemporary art and reflect the living inquiry, curriculum, and art of the educator and young learners.

Keywords: relational aesthetics; contemporary art; a/r/tography; action research; art as experience

\section{Overview}

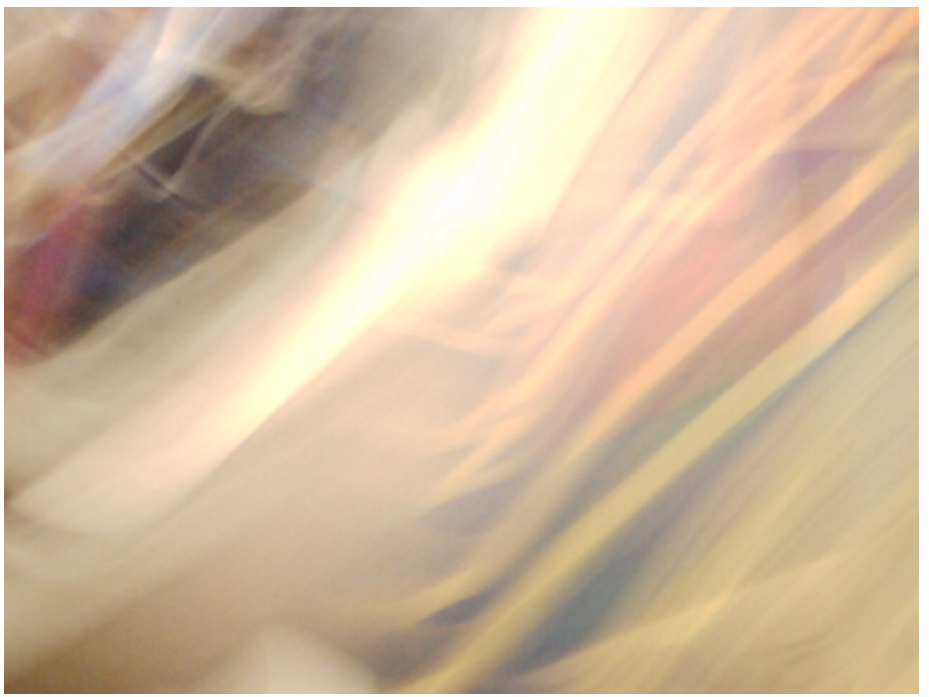

Fox (2001) notes the capacity of contemporary art "to stop us in our tracks, to break the momentum of current themes in educational research, educational practices and educational theory" (p. 33), which provides a point of departure for this research. Specifically, contemporary art has the ability to stop us in our art education tracks, and, within contemporary art, relational aesthetics (Bourriaud, 2001) has the potential to excite new ways to look at curriculum planning, pedagogy, and children's learning in art education contexts. Art provides different ways to consider, imagine, and represent our lived situation (Desai \& Chalmers, 2007). Contemporary art is the art of now, both a mirror and a window to contemporary society, and in that sense becomes "a rich resource through which to consider current ideas and rethink the familiar" (Art 21, 2017, para. 1). Relational aesthetics is an art form that takes its theoretical departure from the social interactions and relations of participants, emphasizing everyday experiences as art.

The research in this paper presents a counternarrative of art education while acknowledging the ever-present state of flux and time of challenge in art education. To ignore contemporary art leaves us unprepared (Garber, 2003). The purpose 
and rationale of this research is to reimagine pedagogy with/in contemporary art practices, namely artful pedagogy, which blends pedagogy and art practice. In this research, relational aesthetics is employed as an approach to teaching and learning; however, the concept of artful pedagogy can remain open ended and adapt to individual educators' interests and areas of curiosity in contemporary art. Art education needs to catch up with the radical changes and pedagogical shifts in contemporary art. The following research is propelled by the moments of relationality that are connective threads and are re/ presented as a blurry photograph at the beginning of each section to illustrate the interconnected nature within this research, relational aesthetics, and artful pedagogy. The section-starting blurry photographs are not listed as figures because they are not supplemental to the research but are rather the interconnection of text and image. The research illuminates, depicts, and explains the complexities and ambiguities of artful pedagogy and asks readers to come to the nexus to gain an openness to new questions about art education practices and inquiry.

Artful pedagogy allows art educators to turn toward contemporary art and infuse their curriculum with concepts and ideas from contemporary art, as well as to develop a pedagogy that looks at art education in a new way. The learning experiences in relational aesthetics as pedagogy are potentially dynamic, layered, and slippery, but children respond divergently, construct diverse meanings, and create unpredictable products (Richardson \& Walker, 2011, as cited in Thulson, 2013). Furthermore, relational aesthetics is an approach to art education that resists predetermined outcomes and strict routines and can incite surprise and discovery. By using relational aesthetics as an approach to learning, educators can infuse contemporary art into the classroom, in their teaching practice, and in the content of the curriculum.

Drawing from both historical and contemporary art education and art research, it has been shown that this topic of relational aesthetics is very timely. As stated above, relational aesthetics as an approach to art education can affect the learning process. The learning experiences in relational aesthetics could potentially provoke learning through critical thinking, engagement, democratic practices, play, development of empathy, bringing new ideas to view, collaboration, and reflection, all which are concerns of the art education field as a whole. A relational aesthetic approach to art education could change the way we teach and the way children learn, as well as develop community and ways of being within the classroom. Furthermore, it would work to maintain the art educator as a creative practitioner using conceptual and relational practices. Artful pedagogy empowers educators to have the courage to establish practices and teaching methods that are based in art.

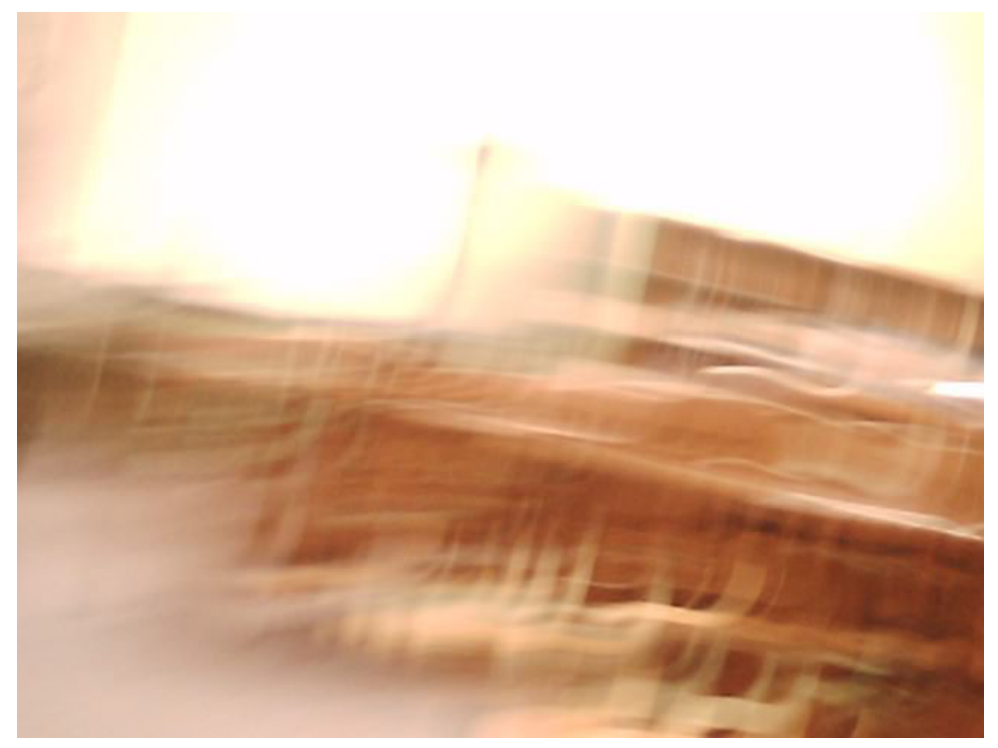

\section{Methods and Participants}

A qualitative method that best fits this research is action research inspired by a/r/tography, the blending of artist, research, and teaching identities for the purpose of academic study (Fraenkel, Wallen, \& Hyun, 2012). Specific notions of a/r/tography, such as evolving questions, blended roles, and the interconnection of text and image, are used in this research. However, the inquiry is a process, rather than a method, that is based in concepts and leaves the inquiry open for unexpected and unpredictable results. $\mathrm{A} / \mathrm{r} /$ tography can be defined as a mode and process of knowing through proximity and relationality that poses different ways of making sense of the world in an ongoing lived inquiry. This definition allows the role of the researcher to be blended with the roles of artist and teacher. It also shows the relationships between text and images. A/r/tography is a hybrid, practice-based form of methodology (Sinner, Leggo, Irwin, Gouzouasis, $\&$ Grauer, 2006). Process in a/r/tography is an act of invention rather than interpretation, where concepts emerge from social engagements and encounters (Irwin et al., 2006). In a/r/tographic research, the art becomes the "visual reorganization of 
experience that renders complex the apparently simple or simplifies the apparently complex" (Irwin \& de Cosson, 2004, p. 31). My research simplified the apparently complex set of relationships, relational moments, and experiences of early childhood art making and teaching.

This research investigates the lived experiences of young learners and their interactions as well as my examination of artful pedagogy, which blends relational art practice and pedagogy. An art practice was used within the inquiry process, and the resulting data are re/presented with text and artistic image. This method is supported by Barone and Eisner's (1997) definition of this practice as a re/presentation of certain aesthetic qualities or design elements that infuse the inquiry and its text. The aesthetic elements are pronounced throughout this research by presenting an image at the beginning of each section and intertwined throughout the data re/presentation. As previously noted, the blurry photographs at the beginning of each section are a metaphor for the moments of relationality within this research. They re/present the idea that those moments are connective threads throughout the entirety of the research. The blurry nature of the photographs becomes increasingly interwoven, complicated, and complex as the sections unfold.

\section{Description of Young Participants}

The participants were preschool children I had previously taught as part of a grant-funded outreach program. I was employed as a museum educator at a modern and contemporary art museum. As part of this program, I visited Head Start classrooms throughout northeast Ohio and created and discussed art with the children. The focus classes in this research were selected based on my employment. I had already taught these children, so they (and their teacher) were familiar with me, thus serving as a convenience sample. Anonymity of all participants is preserved through the use of pseudonyms. The scope of the Head Start program is to serve the needs of low-income families and children with special needs. For the purpose of this research, a focus classroom was selected that had both a morning and afternoon session, and a total of 30 children participated in the research. The classroom is managed by both a lead teacher and an assistant, and the ages of the young learners ranged from 3 to 5 years.

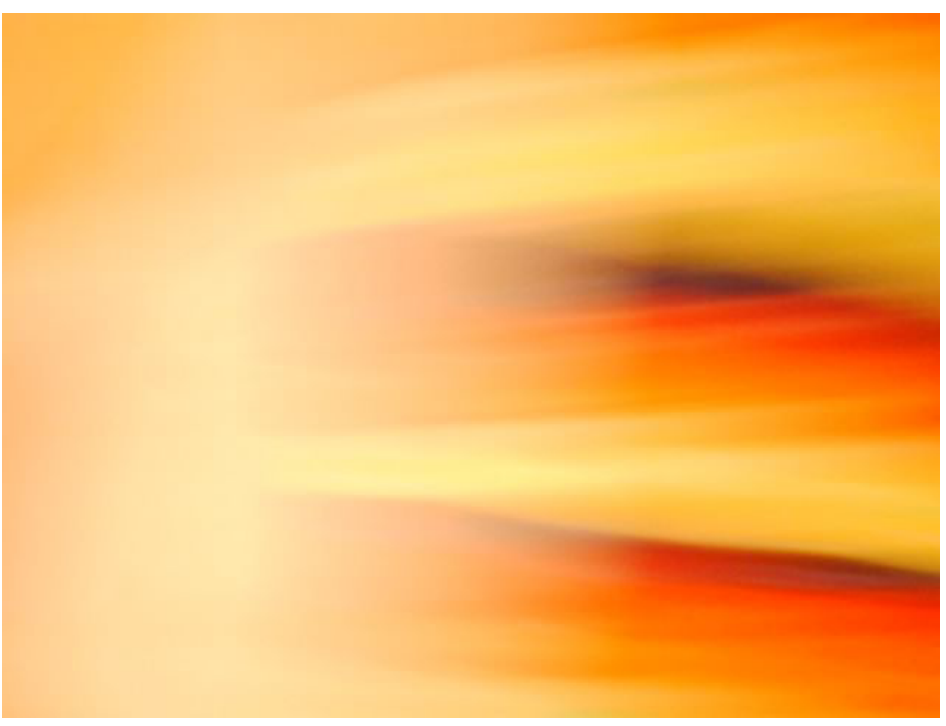

\section{Classroom Experiences}

Thulson (2013) discusses the use of the so-called School Art style commonly associated with elementary classrooms, a style that stresses product over process. Thulson brings to light a critique of art lessons that focus on the product, or what can be hung in the hallways. She notes four obstacles to using contemporary art pedagogy in the elementary classroom. These obstacles include buy-in from parents and administrators, as well as a fear of what children may be able to understand as far as concepts and ideas in contemporary art.

For the classroom experiences I conducted with early learners, I used Thulson's article as a guide and adapted it to fit the needs and interests of the children in the focus class. The following sections discuss the planning process and inspiration for the classroom experiences and what happened during those experiences. Contemporary artworks and artists are discussed to present ideas and forms of contemporary art. 


\section{Unpredictable Projects}

As part of a previous classroom experience, I asked children to document their art-making process through the use of digital cameras. As I explain more fully throughout this paper, when I viewed the photographs, there were always blurred and outof-focus images that were strongly aesthetically pleasing to me. I began to collect and sort these serendipitous images after each classroom experience. When viewing and discussing the work of Katharina Grosse, a theme emerged from the young learners' discussions: mistakes. I discuss the concept of mistakes in the following sections. This emergent theme allowed the class to make use of the blurry images, and I was able to gather their responses in a large-scale installation. The blurred photographs therefore became the material and subject matter of the artwork the children created. This approach to the classroom experience gave the children the opportunity to compare the small-scale photographs they took to the large-scale installations by the artist Grosse.

Grosse's work is known for a vibrant palette and large gestures. Her installations merge painting, sculpture, and architecture, and often take the form of painted interiors and exteriors of buildings. As noted on the Massachusetts Museum of Contemporary Art (MASS MoCA) website, Grosse uses a spray gun instead of a brush, painting directly on the walls, floors, and facades of her exhibition sites. Often, Grosse's installations incorporate a variety of unexpected objects that also get painted directly on and confuse the floor and ceiling. Her work seems like a flow of colours and rearranges conventions and habits of seeing. In a 2011 interview for Artforum's website, Grosse discusses how her installations function as an expansion of small experiences, and she goes on to say that, by transforming something small into something large (her installations), the time and information are presented like slow motion (Artforum, 2011). The blurry photographs made by the children in the focus class are metaphors for the moments and gestures of learning that are very small experiences; however, this research makes them larger, slowing down the information and giving the children time to reflect on this experience: How could we create an installation similar to Grosse's (see Figure 1) that slowed down time and enlarged a small experience?

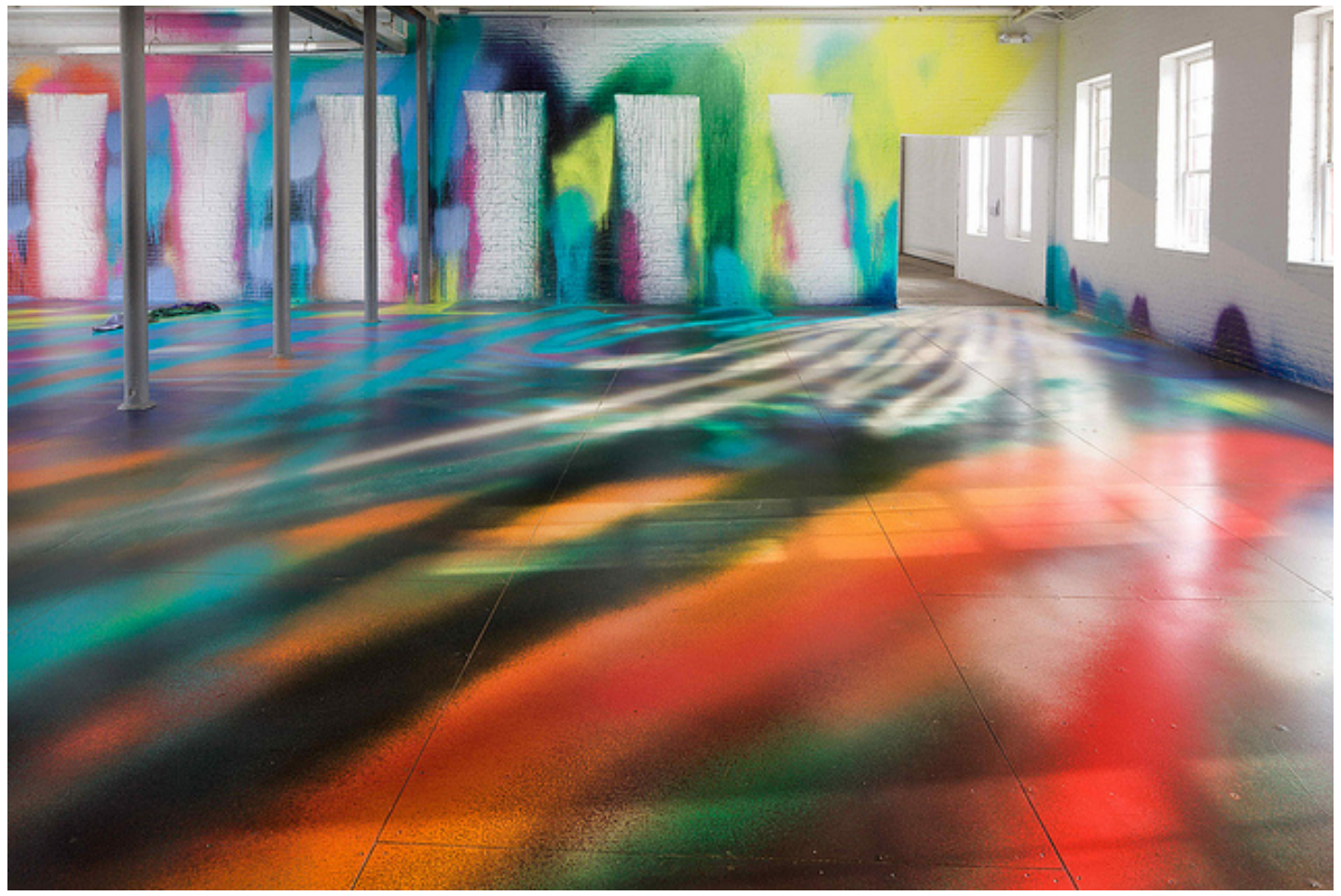

Figure 1. Katharina Grosse "One Floor Up More Highly" installation (2010). Source: Massachusetts Museum of Contemporary Art (2011a) 
In the Artforum interview, Grosse mentions the idea that she does not have a set of rules for her artistic thinking; there are no predetermined outcomes. Similarly, the discussion of unpredictable projects, surprise, and emergent curriculum with contemporary art (Brunson Day, 2009; Kaihorvita-Rosvik, 2009; Kirlew; 2011; Thulson, 2013) indicates that the role of both educator and children in this unpredictable project will change when the curriculum and teaching methods change.

\section{Young Learners as Experts: Social Art}

The second approach to the classroom experience was to find a contemporary artist who works with ideas and themes that were similar to the topic of interest in the focus classroom. At the time, the children were beginning to investigate growth. Additionally, the children had been studying and investigating flowers in their classroom and had plans to create a garden in the yard around their school. The artist Lee Mingwei was introduced to the children for his use of flowers. Mingwei creates relational installations that focus on the viewers' interaction in a personal way.

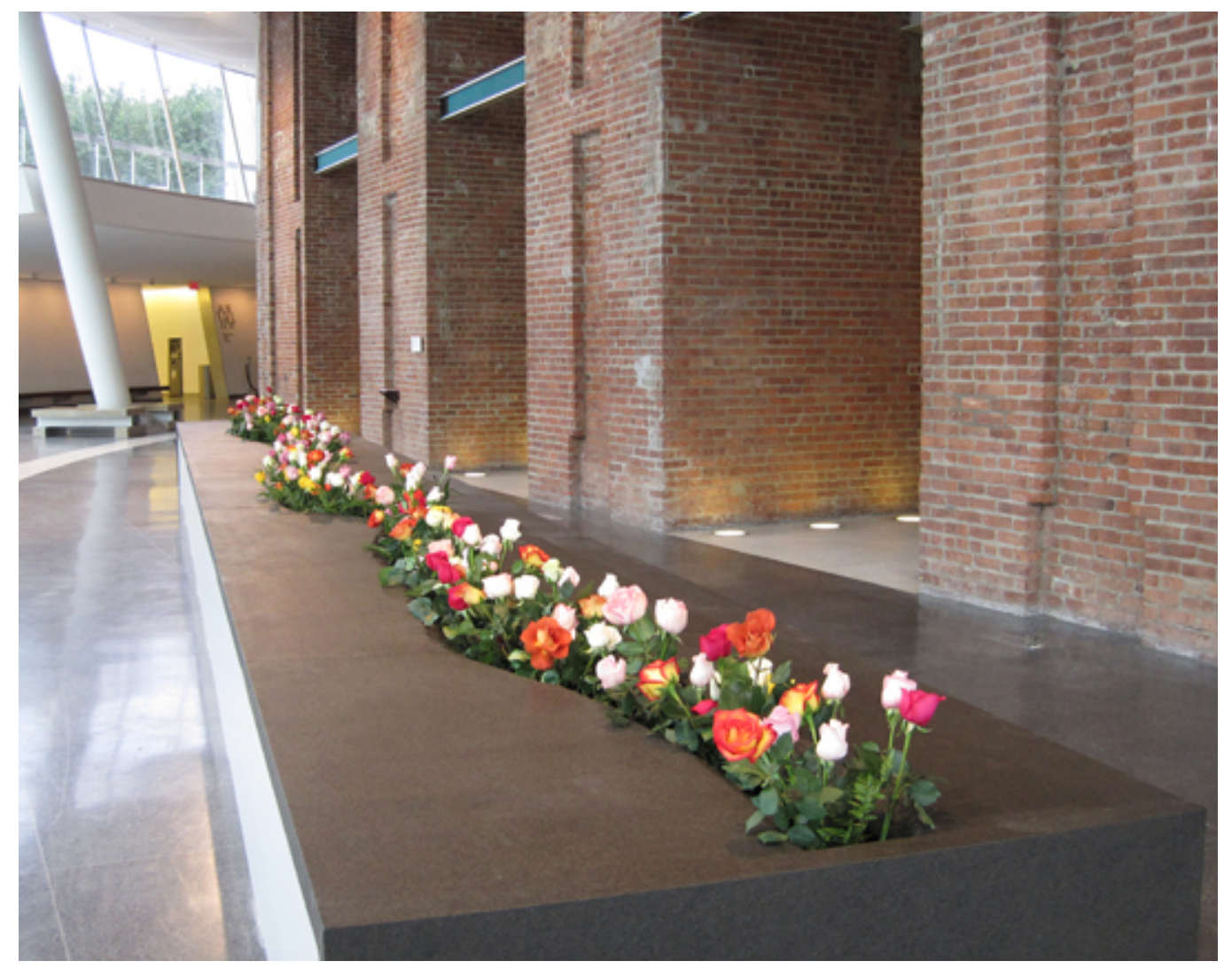

Figure 2. Image of Mingwei’s “The Moving Garden.” Source: Brooklyn Museum (2011)

Mingwei's works are interactive, conceptual, participatory installations that set open-ended scenarios for everyday interaction. The interactions take on different forms depending on the participants. Introducing such an art practice to the curriculum and challenging children with new concepts of art addresses and highlights the importance of the children's needs and interests and incites experiences of otherness and social interaction or cohesion (Anderson, 2003; Helguera, 2011; Illeris, 2005).

The particular artwork that was discussed with the children was “The Moving Garden" (see Figure 2). This artwork, installed in a museum, was a long table with a river shape down the middle. The river was filled with water first and then the artist put 
fresh flowers into the water. The museum visitors were invited to take a flower with them as they left. However, the artist presented two stipulations: Those who took flowers needed to complete two tasks. First, they were to take a detour to their next destination and, when on the detour, to give the flower to a stranger as a gift. The artist did not document what happened once the flowers left the museum. On his website, Mingwei (2011) notes: "We rarely learn how far our kindnesses extend" (para. 3). Mingwei's work, specifically this installation, expands the definition of art and relates to relational aesthetics in that the art is not just something to look at but something to experience. Viewers of the artwork become participants in a relational experiment.

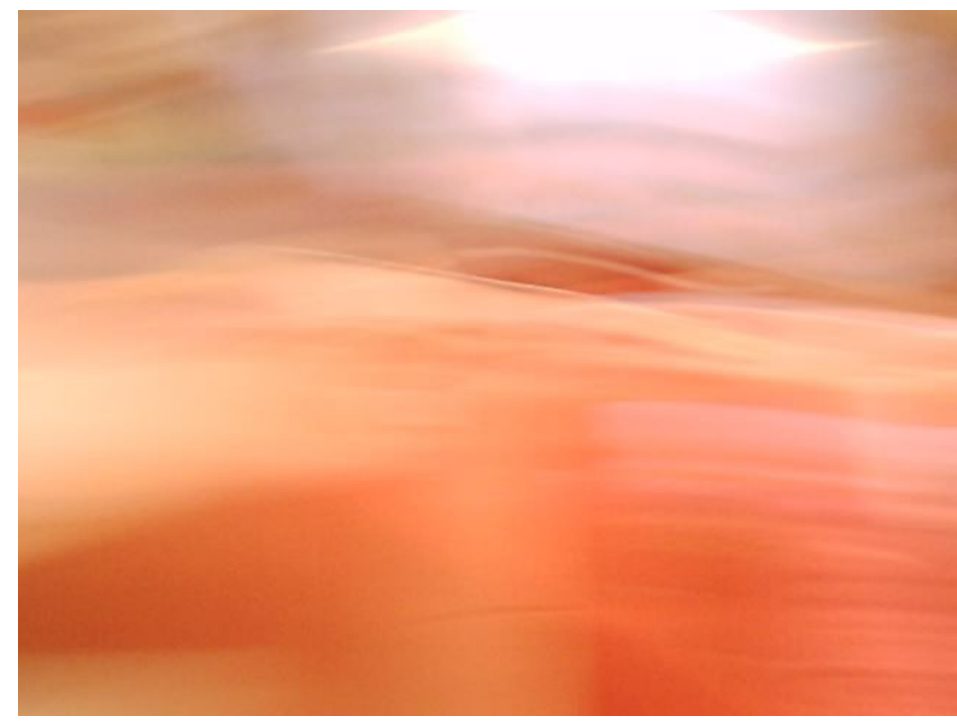

\section{Visualizing Classroom Experiences}

The children's artworks and the transcriptions of the recorded classroom experiences serve as an artifact of the experiences, although I will never understand their experiences fully. All I can do is reflect on the experiences and try to re/present them. Documentation in art education traditionally exists only in the product of the learning, not the process; however, this research attempts to illuminate the process and how the process becomes an integral part of learning. Part of the process is the relational moments that are shown throughout. Furthermore, relational artists have had to find new ways of exhibiting their artwork and propelling the cache of the art experiences they set up. In my re/presentation of the children's art experiences in this article, the interaction of text and image will assist the reader in gaining an understanding of the data and interpretation.

Within my research, the young children saw contemporary art and could potentially relate it to their own messy learning process. The children perhaps saw this contemporary art as an experiment in play. Contemporary art often takes the form of an experiment in play. In art education, we can take this idea and expand what we define as art for young children. Children who are introduced to a variety of contemporary art forms can expand those aforementioned expectations and mimic the experiments in play for their own learning. Furthermore, art education provides the opportunity for children to work toward not a "right" answer but rather their own interpretation.

Research in art education discusses interpretation of artwork by young learners, which is similar to the stages of artistic development. Kerlavage (1995) notes that young learners' ideas about art, their verbal responses and concepts of style, and their personal preferences develop through three progressive and sequential stages: (1) the sensorial, (2) the concrete, and (3) the expressive. However, recent literature refers to social ways of knowing art and has expanded the concept of art, suggesting that "our daily interactions involve learning through images and objects that represent knowledge and mediate relationships between creators and viewers" (Freedman, 2003, p. 89). I argue that ideas about art and interpretation are not stage like, but are heavily determined by individual interests and experience.

\section{Reflection and Analysis of Unpredictable Projects}

During the photo-taking time, the children interacted with each other. Although they were not given a specific subject to photograph, they often took pictures of each other. They would let each other know when the picture had been taken by saying things like "I got your face" or "Let me take a picture of you" or "You're taking pictures good. Say "cheese." I noticed that the children often talked to each other while taking the photographs. They really liked to take pictures of each other. I wondered, in my field notes, "What is typical of preschool children's peer interactions?" I also saw a trend of the 
children giving directions and instruction to each other on such things as where to stand to take the photographs and how to use the cameras. However, from the classroom transcriptions, I did not notice any instances of children asking each other directed questions.

During the second session with this project, the children viewed their "mistake" images (throughout the previous sections these images were referred to as blurry, but in this section the term mistake is used because it was the term the children selected). Examples of the mistake images are shown in Figure 3.
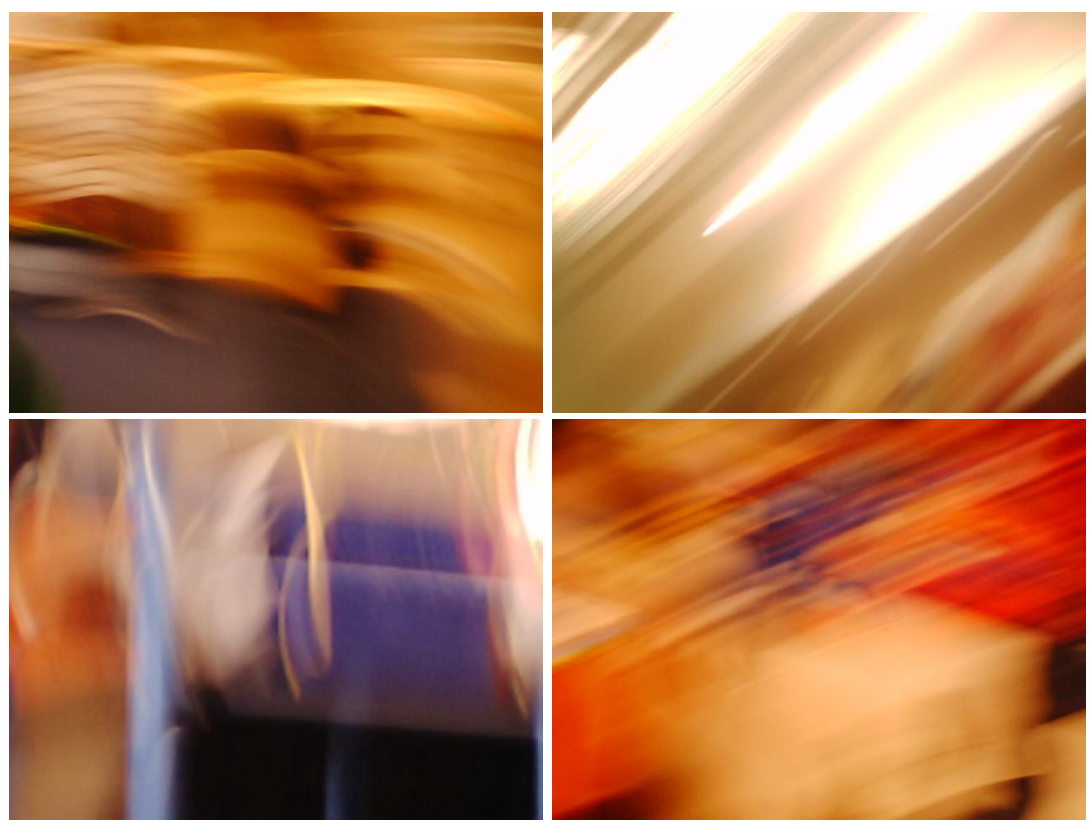

Figure 3. Examples of "mistake" images created by preschool children.

Throughout the two sessions with this group, I noticed that the discussions and conversations about the artwork went relatively smoothly. The children made observations about the artworks that I had not anticipated. Generally all the children had something to share. In certain instances during the discussion, I could hear children propelling forward or even finishing each other's ideas or thoughts. For instance, one child would mention something and then other children would elaborate or provide evidence for the first child's observation. This observation is significant because it implies that very young learners may not be as egocentric as developmental psychology asserts.

When it came time to make the final collages, however, the children were not as focused. Consequently, the art making took more guidance and specific instruction. This finding implies a need for more social interaction in art education versus isolated, individual engagement. Intentional interactions can begin at the early stages so that children are ready to continue this practice beyond preschool. These intentional interactions can take the form of large- or small-group discussions as well as collaborative artworks.

In art education, school art typically results in one artwork made by one child. A focus on the individual is reinforced by the way curriculum is created and the rigor of assessment. Furthermore, children's art shows award individuals. However, I have noticed through my research that although each child creates something (i.e., one child, one work), those works became part of a whole. Similarly, a conversation participant discussed the studio approach in early childhood in contrast to approaches to learning within art education, saying, "[The studio approach is] more about being a part of a group or part of a whole. And recognizing your value inside that, but recognizing the equal value of everyone else's ideas, too" (B. Franklin, personal communication, November 2012). Within the art experiences that were set up for the children, each child contributed to 
the larger-scale artwork, and ownership of a particular photograph or part of the project was not the focus. This served, in my opinion, as a very important reminder to art educators to encourage and provide opportunities for collaboration versus individualism, which is supported by the ideal of building community in the classroom. The children's ideas of mistakes led to the overall concept of their unpredictable project. The individual photographs the children took were cut up (no longer attributed to an individual) and placed in a larger work that was representative of a group effort.

This research affirms the importance of collaborative and social (hence relational) artworks and experiences created in schools. The next section reflects on the project, which took collaboration and an expanded definition of art into consideration and, with feminist pedagogy as a concern, created a site where we can change how we think about ourselves in relation to others (Thompson, 2003).

\section{Reflection and Analysis of Young Learners as Experts: Social Art}

After discussing the artwork of Lee Mingwei with the children and preassessing what they knew about flowers, the children made drawings. The discussion of the artwork did not flow smoothly and was strongly guided by me. The art making, however, seemed to be more fluid for these children in comparison to the conversations. While the children made their drawings (see Figure 4), it gave me the opportunity to interact with each of them and document what they could share with me.
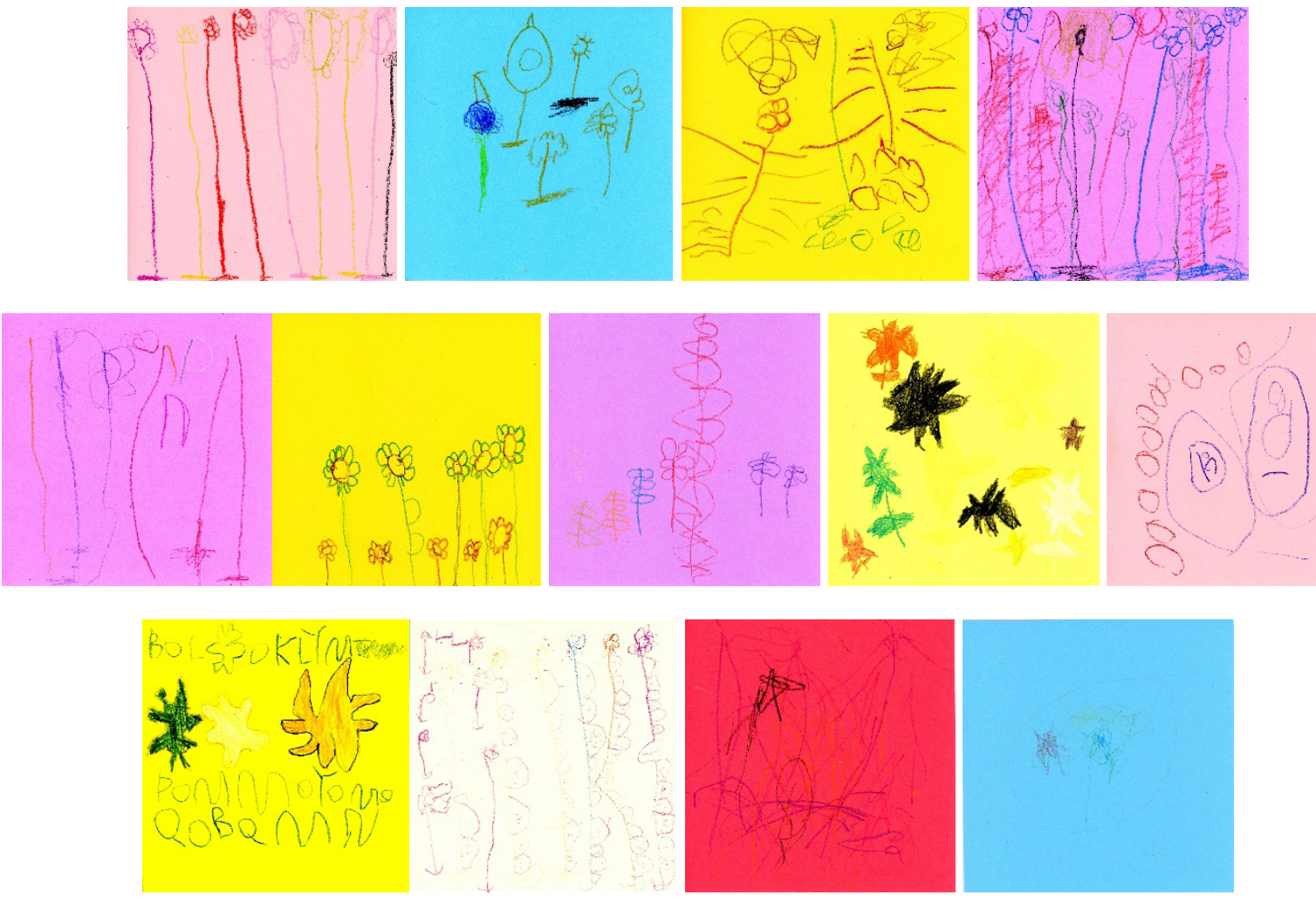

Figure 4 a-m (left to right, top to bottom). Images of flowers that children drew as a preliminary part of the process.

At one point I reflected, "To be honest, this class was much more of a challenge than I had expected. There were two English language learners and one child who had autism and was nonverbal. This led to challenges with communication and interactions. I did notice that when the children started to draw flowers, the language/communication barrier seemed 
to break down. Every child worked hard to create their pictures of flowers and was much more engaged in making than in talking. It didn't make a difference what language they spoke or didn't speak" (field notes, April 16, 2013). The flow of communication that happened visually in this research is akin to one conversation participant's art practice in which she noted a "private language" with young participants in her art (M. Bordin, personal communication, December 2012). This conversation participant is a contemporary artist who creates abstract sculptures and then invites young children to critique and revise her artwork. In personal communication she noted that this experience allowed for a private language or a unique communication that occurred among the young children, the artwork, and her. I was reminded of this observation when I listened to the audio recording of this portion of the class: The children talked with each other about their work even though during the discussion portion of the class, there was no interaction among the children.

To correlate the children's artwork with the verbal interactions, please refer to images a through m in Figure 4.

I dictated what the children said to me when I asked, "What can you tell me about your work/flowers?" Asking this question gave me the opportunity to interact with each child individually. I could then gather their reactions or engagements with the ideas that had been presented and discussed as a larger group. Also, this was the opportunity for the young learners to tell me what they knew and what they were working on, rather than me placing my own interpretation on the images without any input from the makers of the image. Something I noticed while analyzing these images was that the children who drew the most details gave the least amount of verbal response when asked to discuss their artwork. For example, Farrell, in reference to his image (Figure $4 \mathrm{~m}$ ), said: "Flowers can grow and you can smell them. And you give them to people: your brother and your grandma. And you can see your grandma and grandpa get flowers." Farrell's flowers are lightly drawn and show very few details, yet when asked to speak about what he knew, he gave a vivid description of a relational moment. His drawing of flowers gave no indication or illustration of giving flowers or even an image of his family members, yet that was the meaning he attached to this drawing. This finding might also imply that very young children may not have yet developed inhibitions in their thinking.

The meaning of Farrell's flower drawing could have been influenced by the class discussion of the artwork by Lee Mingwei. When discussing Mingwei's "The Moving Garden," many of the children took note of the people who were in the pictures of the artwork. One child mentioned that "the man is putting flowers in there so the girl can be happy." From the children's comments, I could deduce that showing reproductions of the installation with people surrounding it allowed the children to notice the relational focus of the artist's work. Showing the installation in context aided in the children's observations of giving, planting, and picking flowers. As previously noted, when interpreting artworks, children are influenced by their own experiences and the context. I would go on to suggest that children's interpretation of their own artwork is contextual, and that, furthermore, the children assigned meanings and interpretations to their own artwork based on the discussions that had taken place about the art of Mingwei, affirming Ivashkevich's (2009) argument that children's meaning making of art is "a sociocultural practice interwoven with discourses of childhood and gender and embedded in children's peer interactions, daily activities, and participation in popular culture" (p. 50). Within this research, gender discourse was not necessarily the focus of the study; however, it can be noted in the classroom experience transcriptions that more girls brought up ideas and suggestions than boys, suggesting that further study of the classroom transcriptions would be necessary to discuss this discourse. Pearson (2001, as cited in Ivashkevich, 2009) requests that art educators not overlook the contextual complexities of the art process as a lived social and cultural experience. Within my research, children's interpretation of their own artwork and the artwork they viewed resulted in a contextual social practice. Specifically, young learners' artwork and interpretations should be viewed, not as mere visual artifacts, but rather as an interwoven fabric of their daily living and experiences. I wonder, if the children were asked about their work days later, if their verbal responses would be different.

A variety of visual themes seemed to emerge from these drawings. First, I noticed a trend of very long stems for the flowers (see Figures 4a, c, d, f, k). Additionally, there is a series of abstracted flowers that essentially show the pieces and parts of the flower, but they are not located in typical positions (see Figures 4c, j, i). There were also a number of children who coloured in their flowers (Figures $4 \mathrm{~h}, \mathrm{j}$ ). One child in particular seemed to apply a special focus to drawing from life and worked to make her flowers look representational. The variety of visual themes indicated a range in the children's ages and 
developmental stages of drawing. For art education, this finding could indicate the need to have differentiated assessments that are adaptable to each child's level. Not all of the children created artwork the same way, so they cannot be assessed the same way.

Figure 5 illustrates the children's final project. The artwork was a social installation that mimicked the concepts of Mingwei's project.

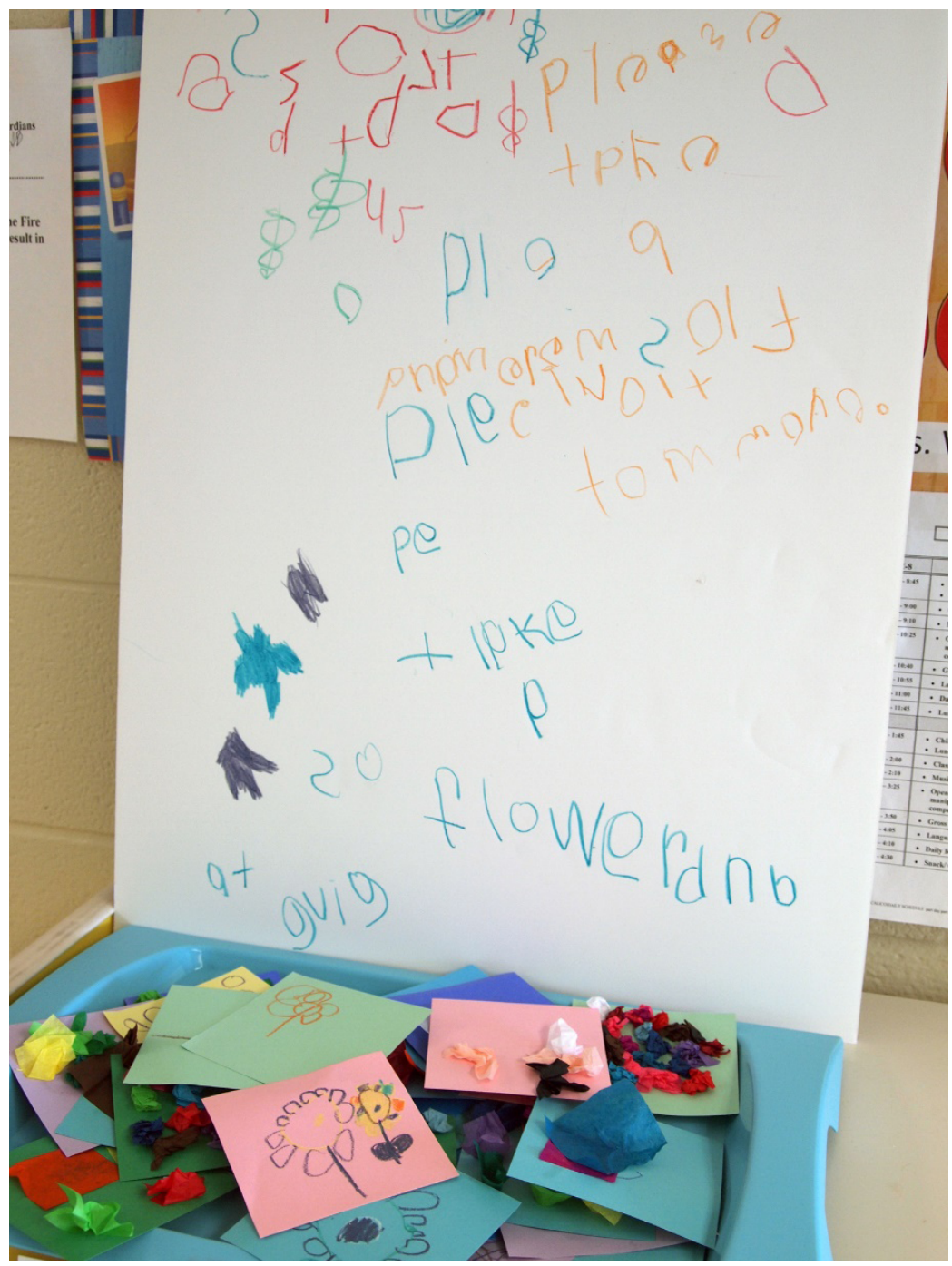

Figure 5. "Moving Garden" project that was created by children and installed in the hallway of the research site.

As previously mentioned, the children seemed more engaged during the art making and they interacted with each other more than during discussion time. I noted in my field notes (April 16, 2013) that "during the final session three children worked extra on their drawings and were having an interesting conversation about each other's work." The interactions between the children during this time took the form of compliments, asking for someone to look at their work, and displaying it to each other. From this finding, I deduce that the children were modelling what I and the classroom teachers had been doing throughout the art making. Their modelling of these activities shows evidence of the developmental level of the young 
learners, where they are learning by example. Furthermore, it highlights the relational nature of classroom experiences.

The children opted to place their installation in the hallway so more people could interact with the artwork. They even created a sign that asked passersby to take a flower and then give the flower to someone else. To follow up the discussion on the first day, I brought in fresh flowers for the children. Like Mingwei, I told them that the flowers were a gift but they were to pass them on to people they saw throughout the day in the school. Although I would have enjoyed witnessing this experience of the children, I decided to not know the "extent of my kindness" and allow it to happen once I left the classroom, paralleling Mingwei's intention. Additionally, these experiences mirrored relational aesthetics in that the outcomes were not immediately visible to me. In my field notes (April 18, 2013) I wrote, "I am excited that I did not see the end result of this social project. Will the visitors to the school feel comfortable to actually take a flower from the installation and then give it away?" In line with the idea of reconceptualizing and reimagining art education, this installation had the power to have adults rethink the image of the child. This research showed that young learners can indeed think conceptually and make that thinking visible through a relational or social art installation. This again goes against developmental psychology, therefore suggesting that a reliance on developmental psychology could limit teaching and artful pedagogy. Additionally, having a contemporary and conceptual installation in the hallway of a preschool was in contrast to the traditional work made by the children. The children and their work have the potential of being a catalyst to have others interact as well as changing the space of their school. This point is further illustrated by an interview participant's reflection on his experience when he was able to

render back to the students something that belongs to them, which is their own creativity, their own agency, their own opportunity to discover their own world and then "speak" about their own world ... the times that I have done that I have seen some of the greatest art produced in the classroom by students. And the truth is at that point it doesn't look like student art anymore, it just looks like art (J. Lucas, personal communication, November 2012)

Similarly, the children in my research created an intervention in their school and not only participated in it but also created a relational artwork, which is a very different gesture to have in an art classroom than most art educators, parents, and administrators would expect or are used to viewing. As a facilitator, I rendered back to the children something that belonged to them: their creativity, their agency, and their own opportunity.

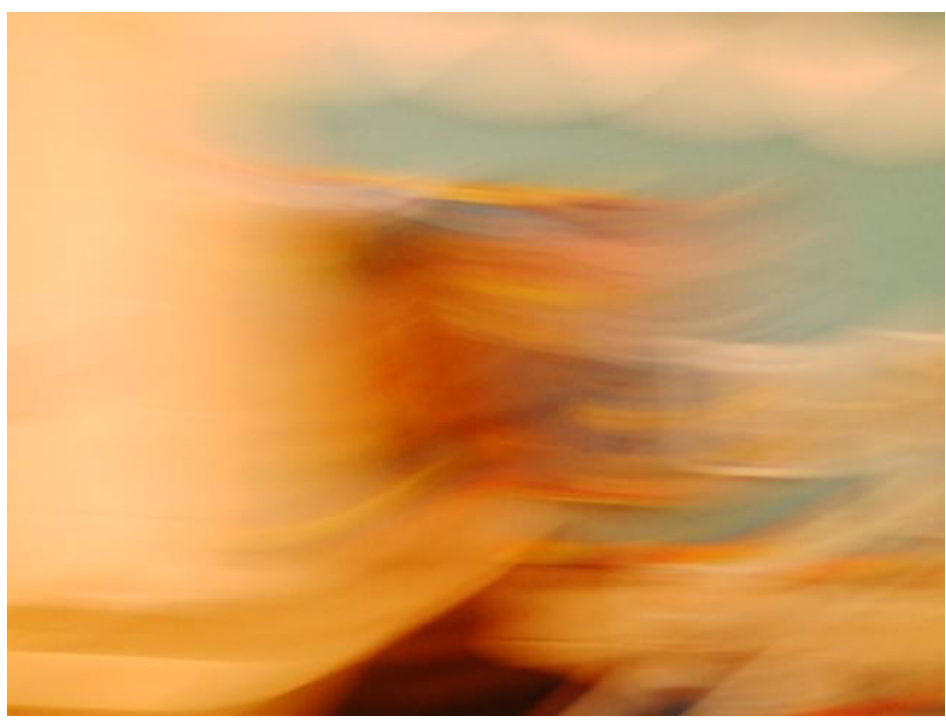

\section{Interactions, Conversations, and Situations}

Interactions are not always having a conversation. They could be ways of being together in the classroom or making art collaboratively. In an intervention, I have to address the strengths of each class: Interactions should not always be set up, evaluated, or understood in the same way. Children and classes interact differently, so I need to interact differently, too. Akin to the Reggio Emilia philosophy, I began to think about the ways early learners can communicate: the ways in which young learners are afforded the ability to think, play, listen, and invent in a multitude of ways.

In this image of the child, the child is understood as a complex individual with the capacity to communicate in a variety of ways. There are essentially infinite ways that children can express, connect, and explore their ideas and thoughts. Furthermore, a conversation participant who works with young learners expressed the idea of nonverbal communication that is developed through a common language and that builds a community in the classroom. She noted, in a description of 
a typical day, that relationships provide children with "a way to talk to one another that isn't just focused on verbal language alone ... and it also gives them gesture, a way to move; it gives them an understanding that is separate from the language and more than their own" (B. Franklin, personal communication, November 2012). The participant's observation and research of young learners' relationships within the classroom is in line with my observations and interpretation of the interactions.

Questions and conversations become an important part of learning in the experiences set up in this research, but they can also be emphasized in early childhood classrooms and, even further, in art classrooms. As highlighted by Dodd-Nufrio (2011) and supported by the Reggio Emilia philosophy, each young learner has the desire to connect with others, to engage in learning, and to enter into a relationship with their environment. In my study, it was evident that children interacted and connected with each other in a variety of ways, including conversations.

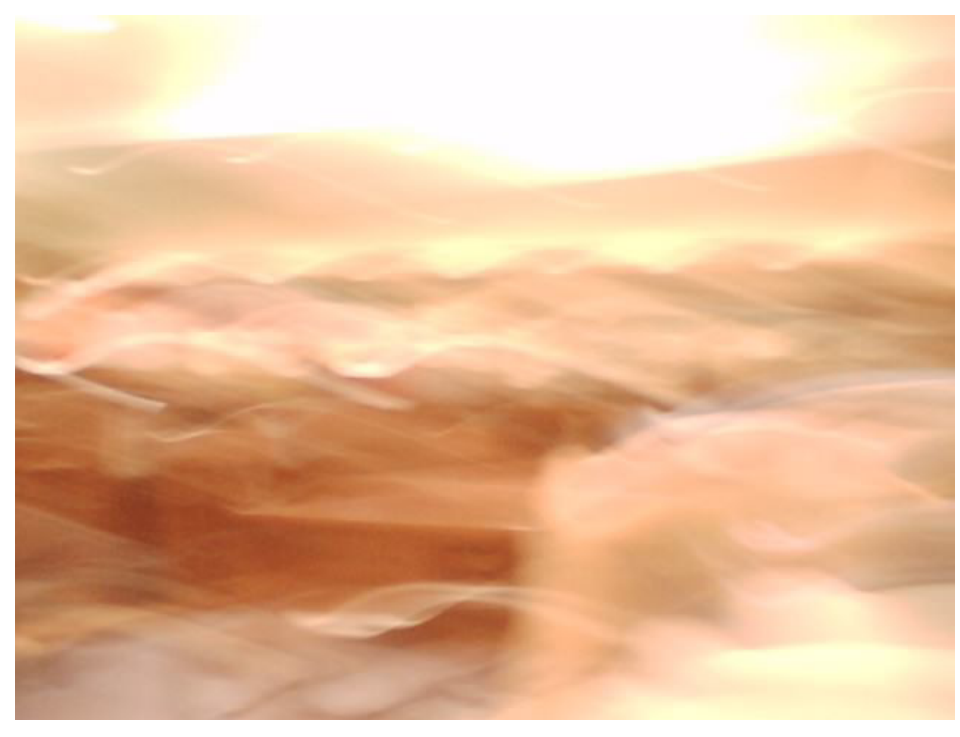

\section{Interpreting Relational Aesthetics with a Pedagogical Lens}

Relational art sets up a situation in which participants interact. As noted above, within my research as well as in relational aesthetics, a level of trust must be present for such interactions to take place (Herring, 2012; Tsai, 2011). Specific artists such as Lee Mingwei and Oliver Herring do this in interactive, conceptual installations where the interactions and process of the individual participants form greater importance than an object or product. Open-ended scenarios (curriculum) for everyday interactions (in school) that take different form depending on participants (children and educators) are both a practice in relational art and also a framework for structuring a classroom. Mingwei notes that his installations changed based on who participated, which could suggest differentiation of instruction, curriculum, and assessment in the art classroom. With this suggestion in mind, the classroom would become very open ended and directed by the interactions and interests of the children. Furthermore, Herring (2012) describes his TASK parties with terms such as expectations, motivations, interpret, instructions, reflecting, and framework, terms usually associated with education. TASK parties allow participants to be engaged in an interactive process. Herring creates a situation in which participants work together creating art and provoking new experiences. The parties start with an objective, but the outcomes are unexpected and emerge as the experience continues. The participants perform a task and create tasks that go beyond the initial objective. In art education, similar concepts could be used when creating curriculum. The objectives are the start of the lesson or curriculum, but children and educators are empowered to work beyond the objective and see what outcomes emerge. Within the art experiences that were re/presented in this research, children were able to work beyond initial objectives. One conversation participant noted a view of objectives and standards in art education and discussed how differing definitions of standards could result in viewing standards as a starting point rather than an end goal. My teaching is similar to Herring's TASK parties in that "almost all of [the participants] ended up doing things and engaging their fellow participants in ways that inspired and challenged them" (Herring, 2012, p. 17). The children in my research ended up engaging their classmates in discussions and inspired and challenged me. As previously discussed, my role in creating an intervention in the classroom allowed me to be a participant in the learning as well. 


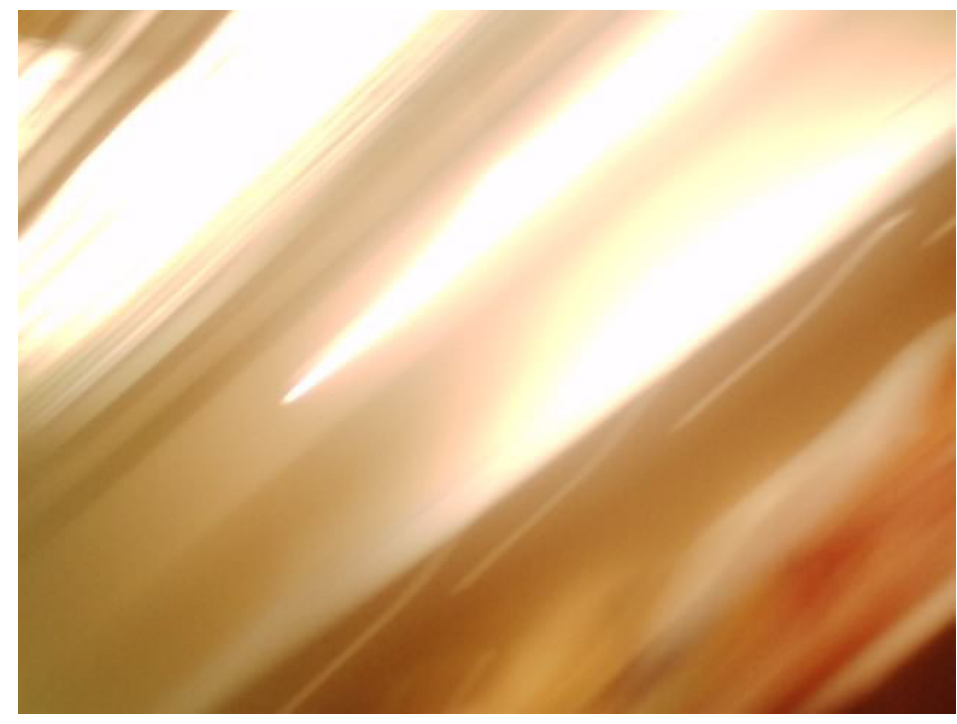

\section{Further Questions for Artful Pedagogy in Art Education}

My contribution to the unfinished and in-flux rethinking of art education has come in the form of relational aesthetics as pedagogy. Contemporary art, specifically relational aesthetics, has stopped me in my art education tracks and revealed new concepts and processes, not only for art making, but also for pedagogy. The research presented in this article presents relational aesthetics in this sense and could furthermore stop others in their tracks, to provide the opportunity to ask new questions and think differently. Throughout this research, the potential of contemporary art in art education has been exposed. The learning within the research remained open ended and was capable of making compelling learning experiences for the young learners and myself. The research has allowed me to "honestly and fearlessly analyze the forms, functions, artistic methodologies and conceptual understandings" (Gude, 2013, p. 8) in my pedagogical practice. In light of Gude's (2004, 2007, 2013) theories, my research can contribute to the reinvention of art education as an ongoing experiment and site of relational aesthetics. Supported by the aforementioned theories, a living curriculum is grounded in the realities of the children's expertise, experience, and context, as well as in contemporary art. Artful pedagogy presents art educators the opportunity to explore and propose new forms and conceptual frameworks of art education. Specifically, Gude (2013) suggests how

[the] classroom's art education curriculum can be conceived of as an ongoing collaborative art project, as an experiment in "relational aesthetics" in which students and others in the school community can interact and create new knowledge by using artistic methodologies to experience and interpret the world in fresh ways. (p. 14)

As seen in this research, the young learners participated in art making and interactions that questioned the tyranny of developmental psychology, specifically, how art teachers "use" or conceptualize artistic stages. Art curriculum based on artistic stages does not allow for children to go beyond expectations. In the experiences in this research, using children's expertise as a jumping-off point created unpredictable projects and reconceptualized young learners' capabilities. Rather than setting predictable outcomes and expectations for the children, the curriculum emerged from their experiences. Both I and the children had to guess and embrace the emergent nature of the projects. Art educators therefore need a more flexible set of expectations for children's abilities to think and work conceptually and be introduced to contemporary art. The learning experiences in relational aesthetics as pedagogy are potentially dynamic, layered, and slippery, but children responded divergently, constructed diverse meanings, and created the unpredictable; young learners are in fact capable to participate in and study contemporary art practices (Thulson, 2013).

Several questions emerged from this research that I am left to grapple with: How can we view children as capable, strong, caring, and full of potential? How does the art educator provide children the opportunity to be stopped in their tracks by contemporary art, regardless of age or developmental stages? How does the art educator conceptualize or use developmental readiness in the art classroom? As a "gutsy possibility" (Fox, 2001), how might young learners participate in research or a/r/ tography practices?

The questions posed above are not exhaustive in nature, but will continue to evolve and emerge as further research continues to compare contemporary art discourses and contemporary art education. Concluding this research provides the opportunity to ask more questions and to look at new directions or possibilities for art education. Akin to Gude's (2013) argument, I suggest 
that contemporary art and relational aesthetics offer a means to look to new possibilities, not just for art education, but for the concept of schools as a whole. This research re/presented artful pedagogy from the viewpoint of a feminist, postmodern art museum educator, but it can incite and open up conversations about artful pedagogy beyond art education. Our challenge as educators is to locate contemporary works of art that make process visible and provide children with powerful art-making experiences that use those conceptual processes and strategies while developing pedagogy and curriculum. Contemporary art prepares art educators for the shifting and challenging discourses in the context of education.

\section{References}

Anderson, T. (2003). Art education for life. Journal of Art and Design Education, 22(1), 58-66.

Art 21. (2017). Contemporary art in context: What is contemporary art? Retrieved from: http://www.art21.org/teach/oncontemporary-art/contemporary-art-in-context

Artforum. (2011). Katharina Grosse. Retrieved from: http://artforum.com/words/id=27257

Barone, T., \& Eisner, E. (1997). Arts-based educational research in complementary methods for research in education. Washington, DC: American Education Research Association.

Bourriaud, N. (2002). Relational aesthetics. Dijon, France: Les Presses du réel.

Brooklyn Museum. (2011). Lee Mingwei: The moving garden [photograph]. Retrieved from: https://www.brooklynmuseum. org/exhibitions/moving_garden

Brunson Day, C. (2009). Teacher as creator. In L. Gandini, S. Etheredge, \& L. Hill (Eds.), Insights and inspirations from Reggio Emilia: Stories of teachers and children in North America (pp. 54-55). Worcester, MA: Davis Publications.

Desai, D., \& Chalmers, G. (2007). Notes for a dialogue on art education in critical times. Art Education, 60(5), 6-12.

Dodd-Nufrio, A. (2011). Reggio Emilia, Maria Montessori, and John Dewey: Dispelling teachers' misconceptions and understanding theoretical foundations. Early Childhood Education Journal, 39(4), 235-237.

Fox, G. T. (2001). Creating research questions from strategies and perspectives of contemporary art. Curriculum Inquiry, $31(1), 33-49$.

Fraenkel, J. R., Wallen, N. E., \& Hyun, H. H. (2012). How to design and evaluate research in education. New York, NY: McGraw Hill.

Freedman, K. (2003). Teaching visual culture: Curriculum, aesthetics and the social life of art. New York, NY: Teachers College Press.

Garber, E. (2003). Teaching about gender issues in the art education classroom: Myra Sadker day. Studies in Art Education, $45(1), 56-72$.

Gude, O. (2004). Postmodern principles: In search of a 21 $1^{\text {st }}$-century art education. Art Education, 57(1), 6-14.

Gude, O. (2007). Principles of possibility: Considerations for a $21^{\text {st }}$-century art and culture curriculum. Art Education, 60(1), 6-17.

Gude, O. (2013). New school art styles: The project of art education. Art Education, 66(1), 6-15. 
Helguera, P. (2011). Education for socially engaged art: A materials and techniques handbook. New York, NY: Jorge Pinto Books.

Herring, O. (2012). TASK. In K. Paitz, I. Berry, \& K. Kileman, Oliver Herring: TASK. Normal, IL: University Galleries of Illinois State University.

Illeris, H. (2005). Young people and contemporary art. International Journal of Art \& Design Education, 24(3), 231-242.

Irwin, R., Beer, R., Springgay, S., Grauer, K., Xiong, G., \& Bickel, B. (2006). The rhizomatic relations of a/r/tography. Studies in Art Education, 48(1), 70-88.

Irwin, R., \& de Cosson, A. (Eds.). (2004). A/r/tography: Rendering self through arts-based living inquiry. Vancouver, BC: Pacific Educational Press.

Ivashkevich, O. (2009). Children's drawing as a sociocultural practice: Remaking gender and popular culture. Studies in Art Education, 51(1), 50-63.

Kaihovirta-Rosvik, H. (2009). Images of imagination: An aesthetic approach to education. Vaasa, Finland: Abo Akademi University Press.

Kerlavage, S. M. (1995). A bunch of naked ladies and a tiger: Children's responses to adult works of art. In C. M. Thompson (Ed.), The visual arts and early childhood learning (pp. 56-62). Champaign, IL: National Art Education Association.

Kirlew, S. (2011). But when are they going to produce some artwork? Against pastiche: Issue-based art and authorship within the key stage 3 curriculum. International Journal of Art and Design Education, 30(3), 379-388.

Massachusetts Museum of Contemporary Art. (2011a). One floor up more highly. Retrieved from: http://www.massmoca. org/event_details.php?id=545

Massachusetts Museum of Contemporary Art. (2011b). One floor up more highly [photograph]. Retrieved from: http://www. flickr.com/photos/massmoca

Mingwei, L. (2011). The moving garden. Retrieved from: http://www.leemingwei.com/projects.php

Sinner, A., Leggo, C., Irwin, R., Gouzouasis, P., \& Grauer, K. (2006). Arts-based educational research dissertations: Reviewing the practices of new scholars. Canadian Journal of Education, 29(4), 1223-1270.

Thompson, A. (2003). Caring in context: Four feminist theories on gender and education. Curriculum Inquiry, 33(1), 9-65.

Thulson, A. (2013). Contemporary practice in the elementary classroom: A study of change. Art Education, 66(1), 16-23.

Tsai, E. (2011). Lee Mingwei: The moving garden. Brooklyn, NY: Brooklyn Museum. 